\title{
Naphthalene diimide-amino acid conjugates as novel fluorimetric and CD probes for differentiation between ds-DNA and ds-RNA
}

\author{
Annike Weißenstein ${ }^{1}$, Myroslav O. Vysotsky ${ }^{1}$, Ivo Piantanida ${ }^{* 2}$ and Frank Würthner ${ }^{*} 1,3$
}

\section{Full Research Paper}

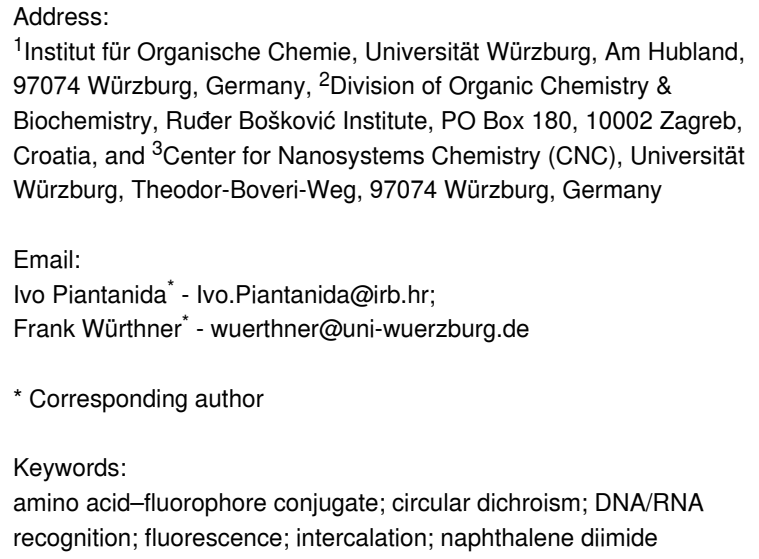

Beilstein J. Org. Chem. 2020, 16, 2032-2045. https://doi.org/10.3762/bjoc. 16.170

Received: 12 June 2020

Accepted: 04 August 2020

Published: 19 August 2020

This article is part of the thematic issue "Molecular recognition" and is dedicated to the memory of Carsten Schmuck.

Guest Editor: J. Niemeyer

(C) 2020 Weißenstein et al.; licensee Beilstein-Institut. License and terms: see end of document.

\begin{abstract}
Two novel unnatural amino acids, prepared by linking a dicationic purple-coloured and fluorescent naphthalene diimide (NDI) at core position to amino acid side chains of variable length, strongly interacted with ds-DNA/RNA by threading intercalation. Different from a reference NDI dye with identical visible range absorbance $(520-540 \mathrm{~nm})$ and Stokes shifts in emission (+60 nm, quantum yield $>0.2$ ), only these amino acid-NDI conjugates showed selective fluorimetric response for GC-DNA in respect to AT(U)polynucleotides. The DNA/RNA binding-induced circular dichroism (ICD) response of NDI at 450-550 nm strongly depended on the length and rigidity of the linker to the amino acid unit, which controls the orientation of the NDI unit inside within the intercalative binding site. The ICD selectivity also depends on the type of polynucleotide, thus the studied NDI dyes act as dual fluorimetric/ ICD probes for sensing the difference between here used GC-DNA, AT-DNA and AU-RNA.
\end{abstract}

\section{Introduction}

The interplay of non-covalent interactions between nucleic acids and proteins or peptides is the basis of life and is also often used for the design of artificial small molecules, aiming for sensing or control of biorelevant processes. Many naturally occurring bioactive molecules contain a short peptide chain and
DNA/RNA interacting aromatic moiety, for instance peptidebased DNA/RNA-intercalators [1,2], as well as many DNA/ RNA groove binding small molecules $[3,4]$. Inspired by these natural examples, the development of novel DNA/RNA targeting synthetic molecules has been in scientific focus for 
several decades, consequently becoming increasingly complex [5-7]. This includes examples incorporating several types of non-covalent interaction with DNA/RNA (intercalation, groove binding, positive-negative charge interaction $[5,8])$ in one molecule or even modified biomacromolecules (e.g., proteins [9]). One of the approaches relies on amino acids conjugated with various DNA/RNA-binding chromophores, thereby yielding effective spectrometric sensing systems due to their interactions with DNA. In this approach, chromophores can be combined with peptide sequences in various ways, thus giving access to large libraries of close analogues. Further, in such peptide-based chromophore systems, a multitude of different chromophores/fluorophores [10] could allow fine tuning of spectroscopic responses to various DNA/RNA sequences. With this concept in mind, Piantanida and co-workers recently developed several series of fluorophore-amino acid conjugates, thereby making use of the availability of $\mathrm{C}$ - and $\mathrm{N}$-terminal amino acid residues for peptide-bond formation. Also, several short multichromophoric peptide constructs were prepared and studied with regard to their interactions with DNA/RNA [11$16]$.

These inspiring results encouraged us to broaden the palette of available amino acid (AA)-chromophore conjugates. Therefore, in this work we have chosen a naphthalene diimide (NDI) chromophore [17-20], a well-known DNA/RNA binding moiety, which differs from previously used dyes by its ability to intercalate into ds-DNA/RNA by "threading" through the polynucleotide double helix $[21,22]$. Such "threading intercalation" indicates that a large aromatic moiety with bulky groups at opposite ends is inserted between two DNA or RNA base pairs, whereby bulky substituents end in both, the minor and major groove of the polynucleotide. Such bulky groups positioning requires the DNA double helix to shortly open at a binding site and close upon threading intercalator insertion. Also, the chosen NDI chromophore is characterised by easily tuneable emission wavelengths [23], and therefore adaptable for the design of FRET pairs with other dyes along the peptide backbone. Such amino acid construct would bring a novel functional property into peptide-multichromophore systems targeting DNA/RNA.

For the design of our new constructs we noticed that the majority of DNA/RNA targeting NDIs is substituted at the imide positions, although such substituted NDI derivatives tend to hydrolyse at the imide positions in basic aqueous environment [24]. It is therefore important during the synthesis and processing to work under acidic to neutral conditions to ensure the stability of the molecules. In addition to the $\mathrm{pH}$ value, the hydrolysis also depends on the position of cationic ammonium groups, namely, the distance of the charged group from the imide position is proportional to its stability [24]. However, too long side chains can interfere with threading intercalation into ds-DNA/RNA. As a compromise, a 3-trimethylammoniumpropyl substituent was uniformly introduced at both imide positions (Figure 1). As shown previously by Würthner and co-workers, amine and halogen substituents at the NDI 2,6-positions have a remarkable effect on the NDI chromophore, as they endow the otherwise colourless and non-fluorescent coreunsubstituted NDI with a new charge transfer band with an absorption maximum in the visible spectral range and a high fluorescence quantum yield (up to $58 \%$ ) [23,25]. Further, the 2-amino substituent offers the possibility to connect various amino acid side chains, thus preparing novel fluorophore-amino acid (AA) conjugates. The amino acids $(S)$-2,3-diaminopropionic acid (L-Dap) and (S)-2,6-diaminohexanoic acid (L-Lys) were chosen to test the difference in the aliphatic linker lengths (Figure 1) on DNA/RNA binding. For comparison purposes, reference compound 5 with 2-(trimethylammonium)ethylamine instead of an amino acid (Figure 1) was prepared.

In our study of the interactions with DNA/RNA weakly acidic conditions ( $\mathrm{pH} 5$ ) were chosen to complement available $\mathrm{pH}$-dependent AA-fluorophores used in our previous research (PHEN-AAs [12,26] and GCP-derivatives [15,27]), which allowed $\mathrm{pH}$ control over DNA/RNA binding. There are several other systems also taking advantage of $\mathrm{pH}$-controlled DNA binding [28], and such $\mathrm{pH}$ control could be further used also in selective antitumour strategies, taking advantage of many solid tumours having significantly lowered extracellular $\mathrm{pH}[29,30]$. That would allow in future research combining of the here studied NDI-AA derivatives with the above mentioned and other $\mathrm{pH}$-sensitive fluorophore-AA, to prepare multicolour spectroscopic probes and eventually also FRET pairs.

Also, the two NDI-AA conjugates $\mathbf{3 a}$ and $\mathbf{3 b}$ have protonatable amino groups at the amino acid side chain, which should be fully protonated at $\mathrm{pH} 5$, thus affording three positive charges resembling the reference compound 5 .

\section{Results and Discussion Synthesis}

Based on the design concept discussed above, the NDIs $\mathbf{3 a}, \mathbf{b}$ and 5 were obtained in three synthetic steps according to Scheme 1, starting from the literature-known dichloro NDI 1 having two 3-dimethylaminopropyl groups attached to the imide nitrogens [31]. This compound was first methylated at the nitrogen atoms by the reaction with iodomethane in refluxing toluene, giving the diammonium NDI 2 in a very good yield of $89 \%$. In the second step, the naphthalene nucleus was functionalized via a nucleophilic aromatic substitution with the Bocprotected amino acids L-Dap and L-Lys. The reaction was carried out in dry DMSO at $60-65{ }^{\circ} \mathrm{C}$ for $1.5-2$ hours. After 


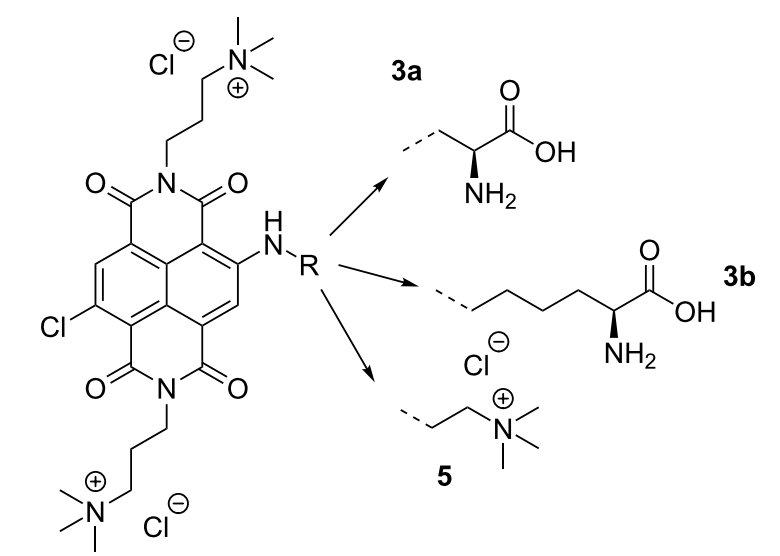

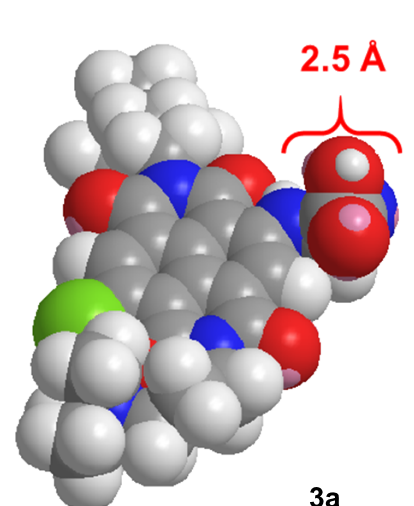

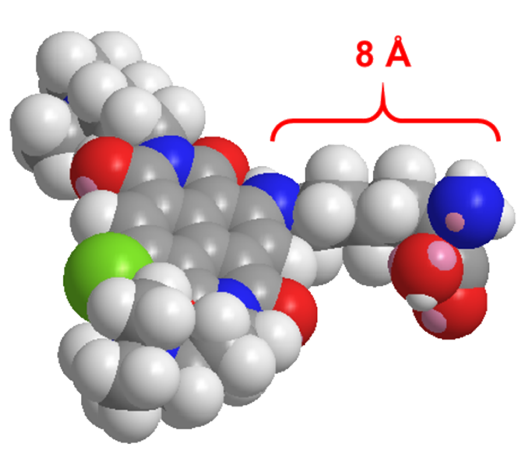

$3 \mathbf{b}$

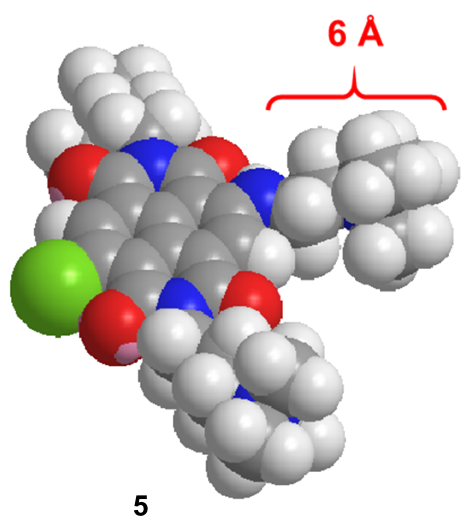

Figure 1: Structures of investigated compounds stressing steric differences in linker length attached to the NDI core.

two preparative HPLC purifications in an acidic environment (with TFA) and treatment with $1 \mathrm{M} \mathrm{HCl}$ solution the Boc protecting group was split off (third step), and the desired NDI derivatives $\mathbf{3} \mathbf{a}$ and $\mathbf{3 b}$ were obtained in a yield of $39 \%$ and $44 \%$, respectively. For the preparation of NDI 5, compound $\mathbf{1}$ was first monofunctionalized at the core with 2-dimethylaminoethylamine in a nucleophilic substitution and then methylated. NDI 4 could be isolated in a yield of $60 \%$ after purification by column chromatography. In the last synthetic step, the molecule was triply methylated with iodomethane in acetonitrile at room temperature for three days. After complete methylation, purification by preparative HPLC and treatment with $1 \mathrm{M} \mathrm{HCl}$ solution, NDI 5 with three cationic substituents at the imide and bay positions could be obtained in $44 \%$ yield. The ${ }^{1} \mathrm{H},{ }^{13} \mathrm{C}$ NMR data, and high-resolution mass spectra correspond well with the structures of all new compounds synthesised.

\section{Spectrophotometric properties of the water- soluble NDIs}

The spectrophotometric properties of the NDIs $\mathbf{3 a}, \mathbf{b}$, and $\mathbf{5}$ were investigated in cacodylate buffer at $\mathrm{pH} 5.0$ for easier comparison with complementary $\mathrm{pH}$-dependent AA-fluorophores used in our previous research (PHEN-AAs [26] and GCP derivatives [27]). Additionally, the stability of similar NDI compounds is greater in weakly acidic buffer solution over a longer period of time [24]. Compounds $\mathbf{3 a}, \mathbf{b}$, and $\mathbf{5}$ revealed absorption maxima of 518-540 nm with molar extinction coefficients of nearly $10000 \mathrm{M}^{-1} \mathrm{~cm}^{-1}$ (Figure 2). Further, 3a, b, and 5 show strong fluorescence at 573-602 nm with significant Stokes shifts $(+60 \mathrm{~nm})$ and quantum yields of 10-32\% (Table 1).

\section{Theoretical calculations}

To get insight into the electronic and optical properties of the 2-amino-6-chloro-substituted NDIs, we carried out computational investigations by using the Gaussian 09 program suite [32]. In particular, we restricted our study to the simplest and general case of the chloro-methylamino-substituted compound Cl-NDI-NMe by cutting the aliphatic chain substituents in the imide positions and considering a methylamino substitution on the core. This simplification is supported by the assumption that the substituents in the imide positions and on the nitrogen on the core are known to have a negligible effect on the chromophore, since both the HOMO and the LUMO have a node at these positions [33]. 


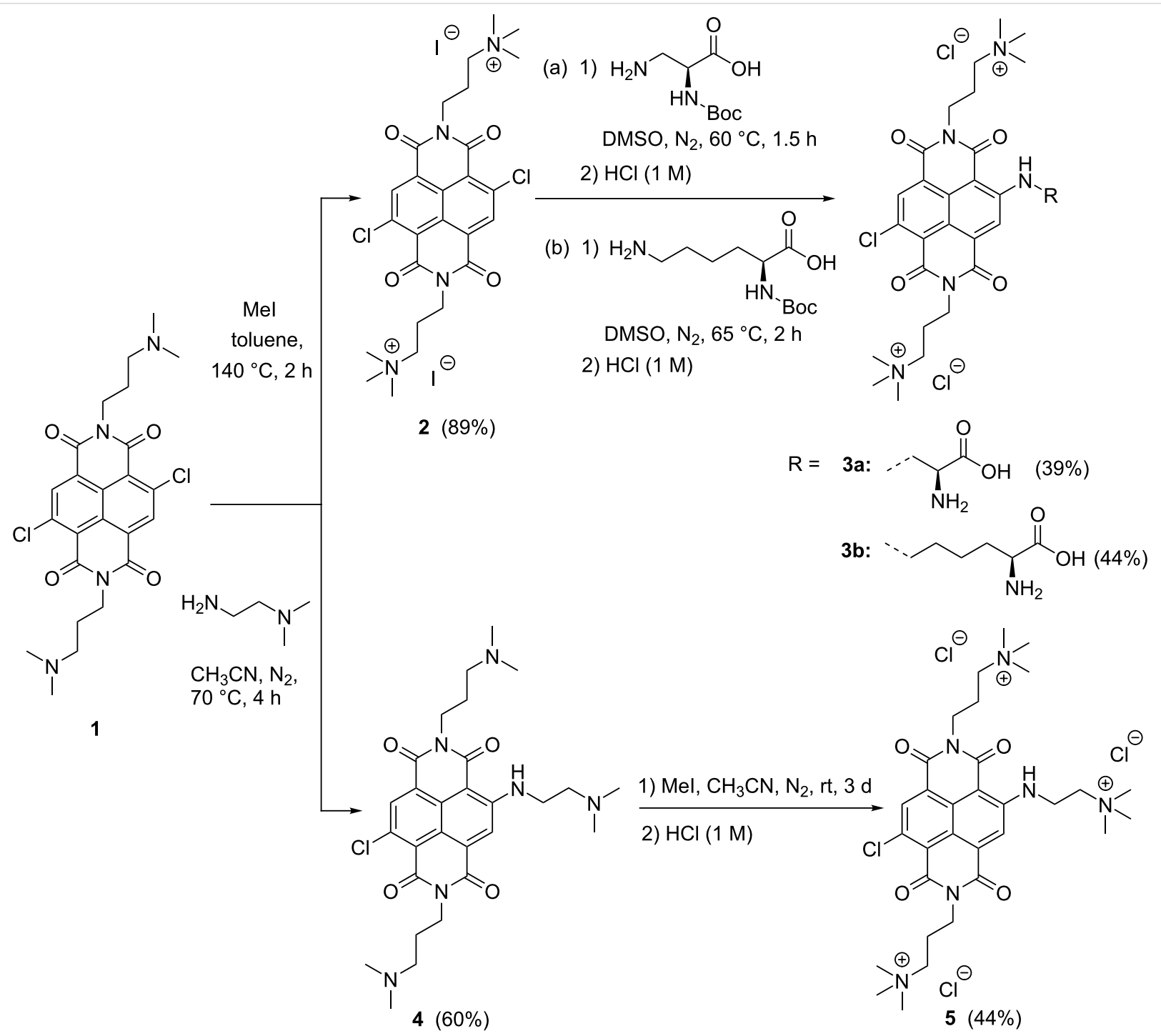

Scheme 1: Synthesis of water-soluble naphthalene diimides $\mathbf{3 a}, \mathbf{b}$, and $\mathbf{5}$.

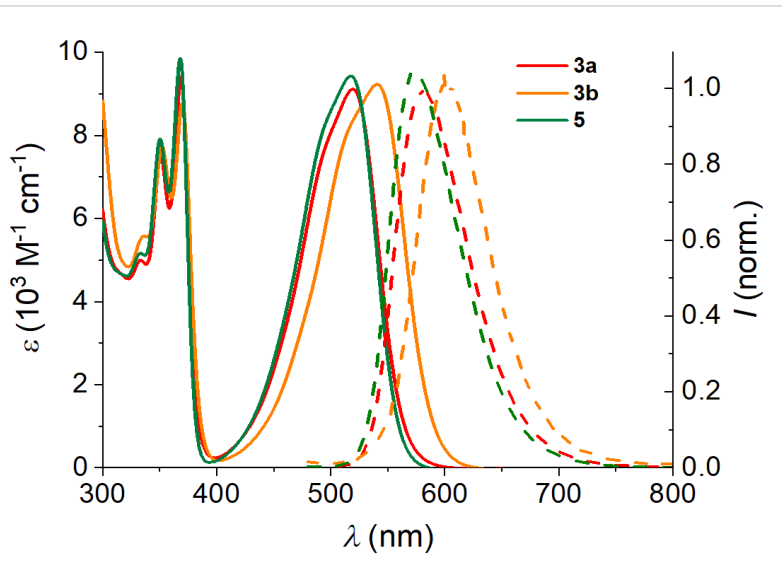

Figure 2: UV-vis absorption (solid line) and fluorescence spectra (dashed line) of NDI $3 \mathbf{a}, \mathbf{b}$, and $\mathbf{5}\left(c=4.5 \times 10^{-5} \mathrm{M}\right.$ in cacodylate buffer at $\left.\mathrm{pH} 5.0, \lambda_{\mathrm{ex}}=470 \mathrm{~nm}\right)$ at $23^{\circ} \mathrm{C}$.
Table 1: Optical properties of $\mathbf{3 a}, \mathbf{b}$, and $\mathbf{5}$ in cacodylate buffer $(\mathrm{pH} 5.0)$ at $23{ }^{\circ} \mathrm{C}$.

NDI $\quad \begin{array}{llll}\lambda_{\mathrm{abs}} & \varepsilon & \lambda_{\mathrm{em}}^{\mathrm{a}} & \Phi_{\mathrm{F}}\end{array}$

$[\mathrm{nm}] \quad\left[\mathrm{M}^{-1} \mathrm{~cm}^{-1}\right] \quad[\mathrm{nm}]$

$\begin{array}{lllll}3 a & 519 & 9100 & 581 & 0.21\end{array}$

$\begin{array}{lllll}3 b & 540 & 9200 & 602 & 0.10\end{array}$

$\begin{array}{lllll}5 & 518 & 9400 & 573 & 0.32\end{array}$

aExcitation wavelength: $\lambda_{\mathrm{ex}}=470 \mathrm{~nm}$ to avoid overlap with emission spectrum.

Geometry optimization by DFT method (at the B3LYP/6$31+\mathrm{G}^{* *}$ level of theory) confirmed a planar and rigid NDI chromophore in the ground state (Figure 3 ). The predicted HOMO and LUMO show remarkable (HOMO) and modest 
a)

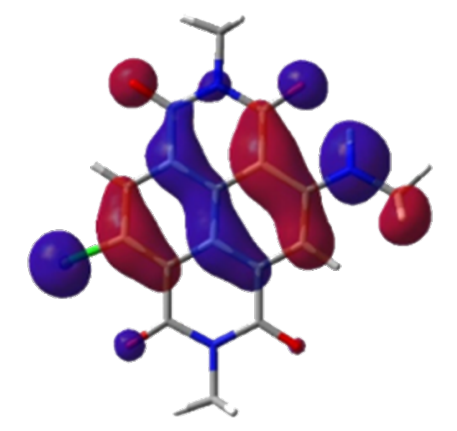

HOMO

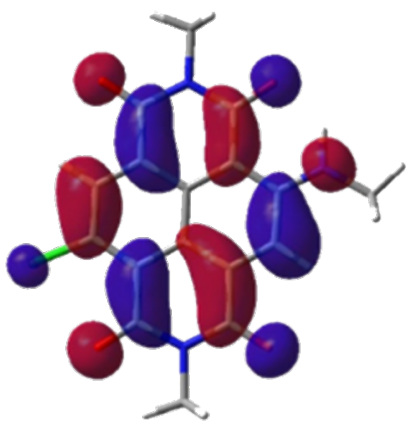

LUMO
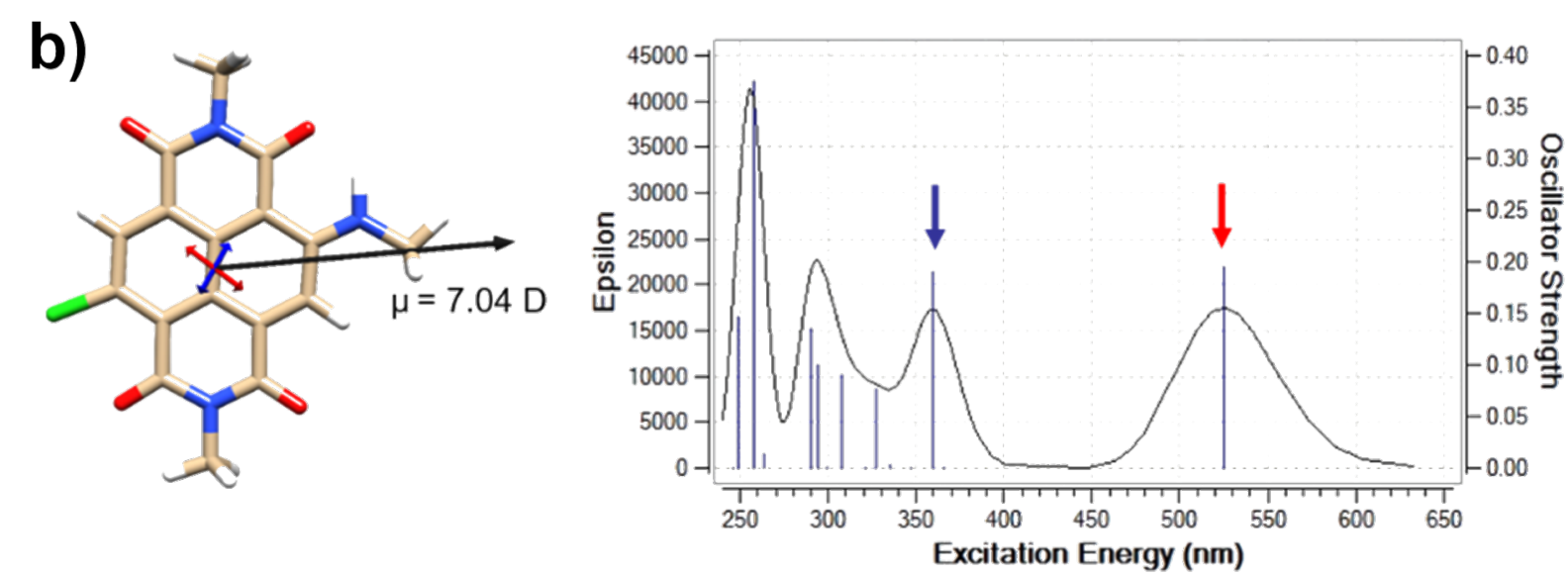

Figure 3: Calculations for Cl-NDI-NMe model compound (at the B3LYP/6-31+G** level of theory) in water (PCM). a) HOMO and LUMO molecular orbitals (isovalue surface $0.03 \mathrm{au}$ ). b) The molecular ground state dipole moment is indicated by the black arrow. The transition dipole moments calculated by TD-DFT (at the B3LYP/6-31+G** level of theory) for the lowest transitions in the visible range of the spectrum (indicated in the spectra by the red and blue arrows) are shown respectively on the structure.

(LUMO) delocalization on the core-substituents which suggest an important contribution of the chlorine atom to the optical features and chemical reactivity [23]. Additionally, the molecule features a high molecular ground-state electrical dipole $(\mu=7.04 \mathrm{D})$, which is an evidence for an intramolecular charge transfer (CT) character of the chromophore [34]. The predicted UV-vis spectra by TD-DFT are in excellent agreement with the experimental one (Figure 3, Table 1, the vibrational coupling is neglected). The transition dipole moment associated with the HOMO-to-LUMO transition in the visible range (red arrow) and with the higher energy transition (blue arrow) are respectively shown superimposed on the minimised structure.

\section{Interactions of $\mathbf{3 a}, \mathbf{b}$, and $\mathbf{5}$ with ds-DNA/RNA}

For a study of interactions with polynucleotides we have chosen synthetic long ds-DNA: poly $(\mathrm{dG}-\mathrm{dC})_{2}$ and poly $(\mathrm{dA}-\mathrm{dT})_{2}$ and ds-RNA: poly(A)-poly(U), as well as mixed sequence ct-DNA ( $48 \%$ of G-C base pairs). The reason for the use of long polynucleotides was to avoid the physiologically non-relevant inter- actions with a short duplex oligonucleotide: for instance, binding of a large aromatic dye by aromatic stacking on the terminal base pairs [35], as a competitive binding mode to expected intercalation. Further, the chosen DNA/RNA polynucleotides are characterised by different secondary structures [36,37]: poly $(\mathrm{dA}-\mathrm{dT})_{2}$ representing the B-helical structure with accessible minor groove at variance to poly $(\mathrm{dG}-\mathrm{dC})_{2}$, which has sterically hindered minor grooves by amino groups, and $\operatorname{poly}(\mathrm{A})-\operatorname{poly}(\mathrm{U})$ is an A-helix with major groove available for binding of bulky small molecules [38]. The interactions of the NDI derivatives $\mathbf{3 a}, \mathbf{b}$, and $\mathbf{5}$ with DNA/RNA were examined first by means of the thermal denaturation method.

Various double-stranded DNA or RNA are known upon heating to dissociate into two single-stranded polynucleotides at a characteristic well-defined temperature ( $T_{\mathrm{m}}$ value). A non-covalent interaction of small molecules usually increases the thermal stability of the ds-polynucleotide, consequently causing an increase of the denaturation temperature $\left(\Delta T_{\mathrm{m}}\right)$. This $\Delta T_{\mathrm{m}}$ value 
can be related to the various binding modes of a small molecule to DNA/RNA [39]. The studies with poly $(\mathrm{dG}-\mathrm{dC})_{2}$ were not possible due to the high melting temperature of $>100{ }^{\circ} \mathrm{C}$.

As shown in Figure 4 and Table 2, the addition of all studied compounds resulted in very strong stabilisation effects on both, poly(dA-dT $)_{2}$ and poly(A)-poly(U). This similarity of stabilisation of ds-DNA and ds-RNA supports the presence of an intercalative binding mode because DNA groove binders are usually strongly selective toward DNA [8]. The NDI $\mathbf{5}$ caused by far the strongest stabilisation - likely due to the three permanent charges. NDI 3b, with a longer and thus more flexible linker, has a higher $\Delta T_{m}$ value than the shorter and less adaptable NDI 3a.

Table 2: $\Delta T_{\mathrm{m}}$ values $\left({ }^{\circ} \mathrm{C}\right)$ of the investigated polynucleotides when $\mathbf{3 a}, \mathbf{b}$, and $\mathbf{5}$ were added in the ratio $r=0.3$ (sodium cacodylate buffer, $\mathrm{pH} 5.0, \mathrm{I}=0.05 \mathrm{M}$ )

\begin{tabular}{lllll} 
polynucleotide & $r={ }^{\mathrm{a}}$ & $\mathbf{3 a}$ & $\mathbf{3 b}$ & $\mathbf{5}$ \\
& & $\Delta T_{\mathrm{m}}\left[{ }^{\circ} \mathrm{C}\right]^{\mathrm{b}}$ & $\Delta T_{\mathrm{m}}\left[{ }^{\circ} \mathrm{C}\right]^{\mathrm{b}}$ & $\Delta T_{\mathrm{m}}\left[{ }^{\circ} \mathrm{C}\right]^{\mathrm{b}}$ \\
\hline $\operatorname{poly}(\mathrm{A})-\operatorname{poly}(\mathrm{U})$ & 0.3 & +17.5 & +25.1 & +30.3 \\
$\operatorname{poly}(\mathrm{dA}-\mathrm{dT})_{2}$ & 0.3 & +21.6 & +28.2 & +35.4 \\
\hline
\end{tabular}

${ }^{\mathrm{a}} \mathrm{r}=[\mathrm{NDI}] /\left[\right.$ polynucleotide]; berror in $\Delta T_{\mathrm{m}}: \pm 0.5^{\circ} \mathrm{C}$.

For an accurate determination of the binding affinity we took advantage of the fluorescence of $\mathbf{3 a}, \mathbf{b}$, and $\mathbf{5}$. Since suspected threading intercalation usually requires longer incubation times, the time required for reaching equilibrium was checked by repeatedly collecting emission spectra upon additions of DNA or RNA aliquots to the dye solution. Accordingly, an incubation period of $180 \mathrm{~s}$ proved to be sufficient.
Generally, the addition of any DNA/RNA resulted in a strong quenching of $\mathbf{3 a}, \mathbf{b}$, and $\mathbf{5}$ emission. However, the emission of reference compound $\mathbf{5}$ was non-selectively quenched by any DNA/RNA (Figure 5c), whereas solutions of $\mathbf{3 a}$ or $\mathbf{3 b}$ showed a stronger quenching for GC-DNA and the weaker for AT(U)polynucleotides (Figure 5a and b). Because guanine is the most electron-rich nucleobase, this behaviour points at a fluorescence quenching mechanism by charge transfer from the electron-rich purine bases to the electron-poor NDI molecular probes.

Processing the titration data by means of non-linear curve fitting to the Scatchard equation [40-42], yielded binding constants $\log K_{\mathrm{S}}$ and binding ratios $n_{\text {[bound NDI]/[polynucleotide] }}$ (Table 3). Although all binding constants are still in the same range $\left(\log K_{\mathrm{s}}=6-7\right)$, our comparison revealed for compounds 3a and $\mathbf{3 b}$ a clear preference toward GC-DNA in respect to $\mathrm{AT}(\mathrm{U})$ sequences. We assume that this is due to the fact that the more electron-rich guanines quench the fluorescence most efficiently via charge transfer interactions with the NDI molecular probes, similar as noted for specific guanine-induced emission quenching of acridine or 4,9-diazapyrene derivatives [43].

In order to confirm the fluorimetric data by an independent method, and also to characterise thermodynamic parameters of complex formation, ITC titrations were performed (Figure 6, Supporting Information File 1, Figures S28-S30), and the results are summarised in Table 3. The values of $\log K_{\mathrm{S}}$ obtained from fluorimetric and ITC experiments were generally in good agreement and minor differences within the same order of magnitude. Also, our ITC titrations revealed for all dye-polynucleotide complexes similar sets of negative enthalpy $(\Delta H$ $[\mathrm{kcal} / \mathrm{mol}])$ and positive entropy $(\Delta S[\mathrm{cal} / \mathrm{mol} / \mathrm{K}])$ values,
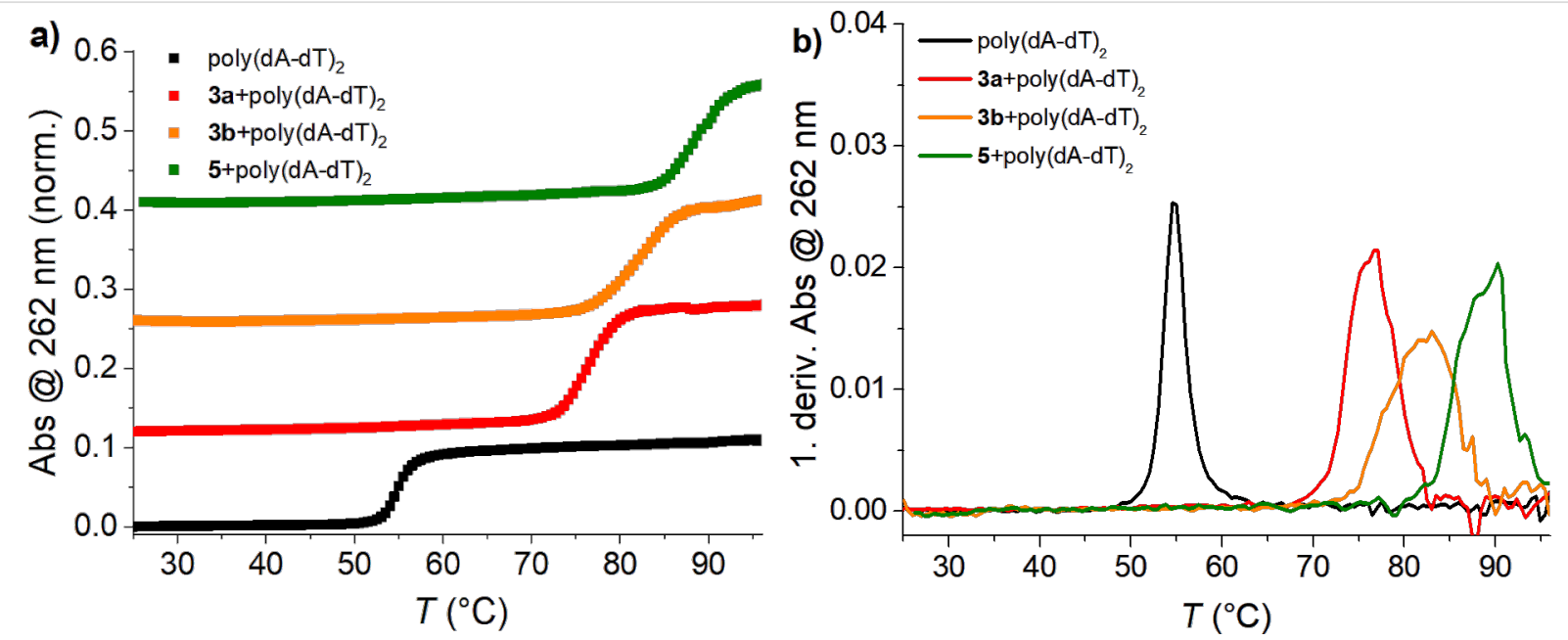

Figure 4: (a) Melting curve of poly(dA-dT) 2 alone and after the addition of NDI 3a,b, and $\mathbf{5}$ ( $r=0.3$ ([NDI]/[polynucleotide])) (sodium cacodylate buffer, $\mathrm{pH} 5.0$, ionic strength $(\mathrm{I})=0.05 \mathrm{M})$. (b) First derivative function of absorption from temperature. 

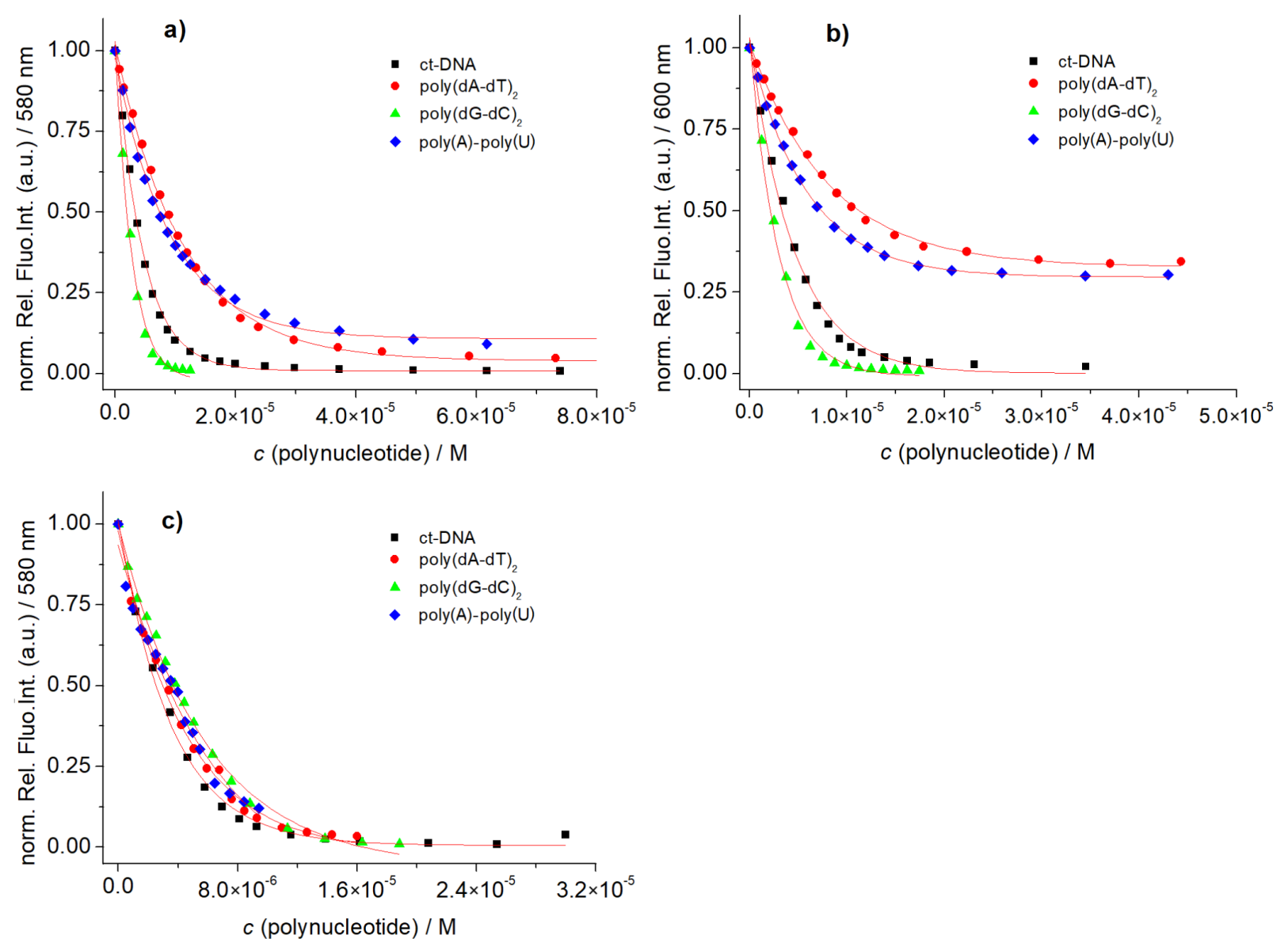

Figure 5: Changes in fluorescence intensity (spectra are normalized) of (a) $3 \mathbf{a}\left(c=1.0 \times 10^{-6} \mathrm{M}\right)$, (b) $3 \mathbf{b}\left(c=1.0 \times 10^{-6} \mathrm{M}\right)$ and $(\mathrm{c}) \mathbf{5}$ $\left(c=1.0 \times 10^{-6} \mathrm{M}\right)$ when adding polynucleotides at $25^{\circ} \mathrm{C}$ (cacodylate buffer, $\left.\mathrm{pH} 5.0, \mathrm{I}=0.05 \mathrm{M}\right)\left(\lambda_{\mathrm{ex}}=470\right.$ nm). Red lines denote non-linear fittings to experimental data by means of the Scatchard equation [40-42].

a)

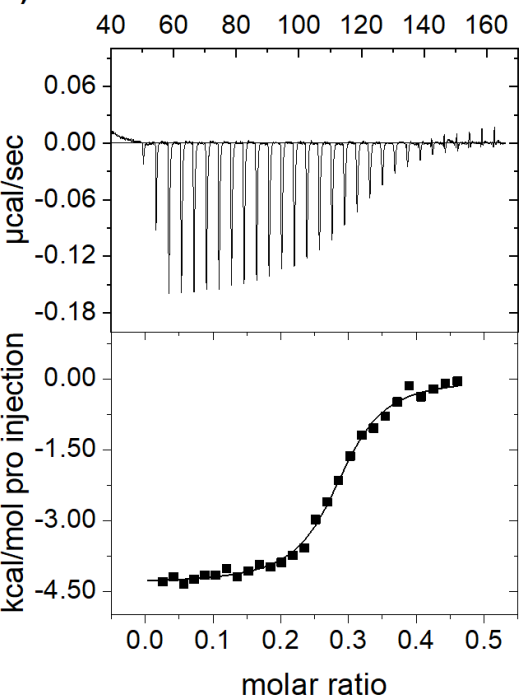

b)

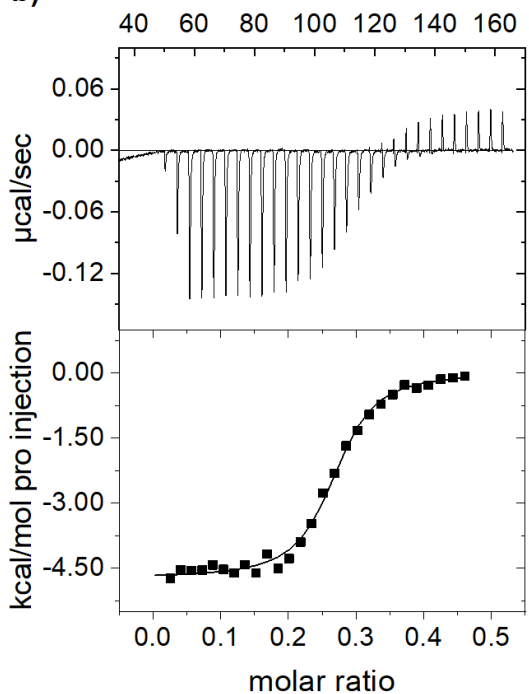

c) $\quad$ time $(\min )$

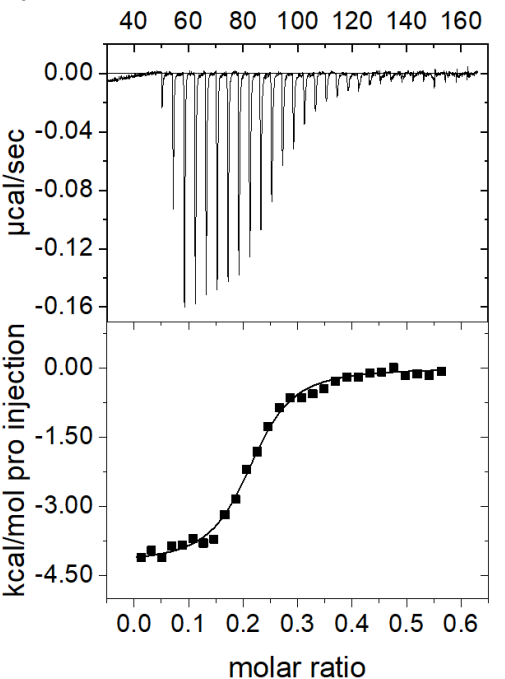

Figure 6: Calorimetric titration of a poly $(\mathrm{dG}-\mathrm{dC})_{2}$ solution in sodium cacodylate buffer (pH 5.0) at $298 \mathrm{~K}$ with NDI (a) $\mathbf{3 a}$, (b) $\mathbf{3 b}$, and (c) $\mathbf{5}$. Top: data obtained after periodic injection of a NDI solution. Bottom: graphs of heat/mol released per injection versus the molar ratio of NDI to polynucleotide. Black lines denote non-linear fitting to experimental data by one binding site model, in agreement with the Scatchard equation. 
Table 3: Binding constants $\left(\log K_{\mathrm{s}}\right)$ and stoichiometry $n_{([\text {bound NDI//polynucleotide] })}$ calculated by non-linear fitting of fluorescence ${ }^{\mathrm{a}}$ and ITC $\mathrm{C}^{\mathrm{b}}$ titrations of 3a,b, and $5\left(c=1.0 \times 10^{-6} \mathrm{M}\right)$ with ct-DNA, poly $(\mathrm{A})$-poly $(\mathrm{U})$, poly $(\mathrm{dA}-\mathrm{dT})_{2}$, and poly $(\mathrm{dG}-\mathrm{dC})_{2}$ at $25^{\circ} \mathrm{C}($ cacodylate buffer, $\mathrm{pH} 5.0, \mathrm{I}=0.05 \mathrm{M})$.

\begin{tabular}{|c|c|c|c|c|c|c|c|c|c|c|c|c|}
\hline & \multicolumn{3}{|c|}{ ct-DNA } & \multicolumn{3}{|c|}{ poly(A)-poly(U) } & \multicolumn{3}{|c|}{ poly $(d A-d T)_{2}$} & \multicolumn{3}{|c|}{ poly $(d G-d C)_{2}$} \\
\hline & $\begin{array}{r}I / I_{0}^{\mathrm{C}} \\
\Delta H\end{array}$ & $\begin{array}{r}n \\
\Delta S\end{array}$ & $\begin{array}{l}\log K_{\mathrm{s}} \mathrm{a} \\
\log _{\mathrm{s}} \mathrm{b}\end{array}$ & $\begin{array}{r}I / I_{0} \mathrm{c} \\
\Delta H\end{array}$ & $\begin{array}{r}n \\
\Delta S\end{array}$ & $\begin{array}{l}\log K_{\mathrm{s}}^{\mathrm{a}} \\
\log _{\mathrm{s}} \mathrm{b}\end{array}$ & $\begin{array}{r}I / I_{0}^{\mathrm{C}} \\
\Delta H\end{array}$ & $\begin{array}{r}n \\
\Delta S\end{array}$ & $\begin{array}{l}\log K_{\mathrm{s}}^{\mathrm{a}} \\
\log _{\mathrm{s}} \mathrm{b}\end{array}$ & $\begin{array}{r}I / I_{0} \mathrm{C} \\
\Delta H\end{array}$ & $\begin{array}{r}n \\
\Delta S\end{array}$ & $\begin{array}{l}\log K_{\mathrm{s}}^{\mathrm{a}} \\
\log K_{\mathrm{s}}^{\mathrm{b}}\end{array}$ \\
\hline $\begin{array}{l}\text { 3a } \\
\text { ITC datab }\end{array}$ & $\begin{array}{r}0.00 \\
-4.22\end{array}$ & $\begin{array}{l}0.17 \\
14.1\end{array}$ & $\begin{array}{l}6.8 \\
6.2\end{array}$ & $\begin{array}{r}0.21 \\
-2.33\end{array}$ & $\begin{array}{l}0.20 \\
19.2\end{array}$ & $\begin{array}{l}6.0 \\
5.9\end{array}$ & $\begin{array}{r}0.04 \\
-3.85\end{array}$ & $\begin{array}{l}0.07 \\
16.0\end{array}$ & $\begin{array}{l}6.0 \\
6.3\end{array}$ & $\begin{array}{r}0.00 \\
-4.33\end{array}$ & $\begin{array}{l}0.26 \\
16.0\end{array}$ & $\begin{array}{l}7.2 \\
6.7\end{array}$ \\
\hline $\begin{array}{l}\text { 3b } \\
\text { ITC data }\end{array}$ & $\begin{array}{r}0.00 \\
-4.26\end{array}$ & $\begin{array}{l}0.15 \\
15.5\end{array}$ & $\begin{array}{l}6.7 \\
6.5\end{array}$ & $\begin{array}{r}0.25 \\
-4.97\end{array}$ & $\begin{array}{l}0.16 \\
13.4\end{array}$ & $\begin{array}{l}6.4 \\
6.6\end{array}$ & $\begin{array}{r}0.31 \\
-3.46\end{array}$ & $\begin{array}{l}0.10 \\
19.4\end{array}$ & $\begin{array}{l}6.1 \\
6.8\end{array}$ & $\begin{array}{r}0.00 \\
-4.72\end{array}$ & $\begin{array}{l}0.23 \\
15.0\end{array}$ & $\begin{array}{l}6.6 \\
6.7\end{array}$ \\
\hline $\begin{array}{l}5 \\
\text { ITC data }^{\mathrm{b}}\end{array}$ & $\begin{array}{r}0.00 \\
-4.41\end{array}$ & $\begin{array}{l}0.21 \\
14.1\end{array}$ & $\begin{array}{l}7.1 \\
6.4\end{array}$ & $\begin{array}{r}0.00 \\
-2.18\end{array}$ & $\begin{array}{l}0.14 \\
23.3\end{array}$ & $\begin{array}{l}6.2 \\
6.7\end{array}$ & $\begin{array}{r}0.00 \\
-2.78\end{array}$ & $\begin{array}{l}0.22 \\
20.0\end{array}$ & $\begin{array}{l}6.6 \\
6.4\end{array}$ & $\begin{array}{r}0.00 \\
-4.23\end{array}$ & $\begin{array}{l}0.14 \\
15.5\end{array}$ & $\begin{array}{l}6.4 \\
6.5\end{array}$ \\
\hline
\end{tabular}

aTitration data were processed using the non-linear curve fitting using Scatchard equation [40] gave ratios of $n_{\text {[bound NDI]/[polynucleotide] }}=0.1-0.3$. For easier comparison, all $\log K_{\mathrm{s}}$ values were recalculated for fixed $n=0.2$. Correlation coefficients were $>0.99$ for all calculated $K_{\mathrm{s}}$ values; ${ }^{\text {bITC titrations }}$ were performed at $298 \mathrm{~K}$ (sodium cacodylate buffer, $\mathrm{pH} 5.0, \mathrm{I}=0.05 \mathrm{M}$ ) and fitted to "One Set of Sites" binding model [46-48] for fixed $n=0.2 ;$ giving enthalpy $(\Delta H[\mathrm{kcal} / \mathrm{mol}])$ and entropy $(\Delta S[\mathrm{cal} / \mathrm{mol} / \mathrm{K}]) ;$ c fluorescence of the NDI-polynucleotide complex $(I)$ and initial fluorescence $\left(I_{0}\right)$ of the NDI calculated according to the Scatchard equation.

pointing out that the complexation processes are enthalpydriven and characterised by the same type of binding mode, i.e., intercalation $[17,44]$. The relatively large entropy contribution might be attributed to the displacement of cations and water molecules from the DNA/RNA grooves [44,45] by side arms interacting with the grooves and thereby supporting the binding.

\section{Circular dichroism experiments}

CD spectroscopy is an ideal method to get insight into the changes of the polynucleotide secondary structure upon binding of small molecules $[49,50]$. Also achiral small molecules can eventually acquire induced CD (ICD) upon binding to chiral polynucleotides, which could give useful information about modes of interaction $[49,50]$. The NDIs $\mathbf{3 a}, \mathbf{b}$ are chiral but the chirality of the amino acid residue is not transferred through the aliphatic linker to the NDI core, since these NDI derivatives do not show intrinsic CD spectra in the range of NDI absorbance (230-600 nm). Titrations of all ds-DNA/RNA with any of our NDIs resulted in a strong increase of the bands at 270-290 nm (Figure 7 and Supporting Information File 1), which are commonly attributed to nucleobase pairs. However, since it is not likely that the chirality of the double helix will strongly increase upon binding of a small molecule, the most prominent changes at $300 \mathrm{~nm}$ and above are most likely attributable to ICD bands of the NDI core bound to the polynucleotide in a uniform orientation related to the DNA/RNA chiral axis $[49,50]$.

Furthermore, differences in the ICD response in the wavelength range from 400 to $540 \mathrm{~nm}$ were observed between our NDI compounds which were most pronounced upon binding to poly (dG-dC) $)_{2}$ (Figure 7). These simple and rather weak ICD signals, along with strong thermal stabilisation (Table 2) and high affinity (Table 3 ) strongly support intercalation of individual NDI molecules between the base pairs of the ds-DNA
[51,52]. Here, their opposite sign (for $\mathbf{3 a}$ positive ICD, for $\mathbf{3} \mathbf{b}$ and 5 negative ICD) points to different orientations of the NDI transition dipole moment with respect to the DNA chiral axis [50]. A positive sign observed for 3a suggests that the long axis of the NDI chromophore is perpendicular to the longitudinal axis of the base pairs (red arrow in Figure 8, for 3a), while a negative one observed for $\mathbf{3 b}$ suggests a parallel arrangement of the NDI dye to the base pairs (red arrow in Figure 8, for $\mathbf{3 b}$ ).

The complexation with poly(dA-dT) $)_{2}$ (Supporting Information File 1, Figure S27) resulted in a negative ICD band (505 nm) only for compound $\mathbf{5}$, whereas $\mathbf{3 a}$ and $\mathbf{3 b}$ did not show any measurable ICD signal, likely due to the intercalation of the NDI chromophore at approximately $45^{\circ}$ with respect to the base pair longer axes, thus yielding negligible intensity of the ICD bands $[49,50]$. A mixed sequence ct-DNA (48\% of GC-base pairs) induced for all three dyes negative ICD signal (Supporting Information File 1, Figure S25), indicating predominantly a parallel orientation for all dyes as shown in Figure 8 for the DNA-3b complex. The absence of any measurable ICD signal for poly(A)-poly(U) (ds-RNA) (Supporting Information File 1, Figure S26) supports the intercalation of all NDI chromophores at approximately $45^{\circ}$ with respect to the base pair longer axes, thus yielding negligible intensity of ICD bands $[49,50]$. Such different sets of ICD band responses, which varied not only with respect to differences in the dye structure but also depended strongly on the DNA/RNA secondary structure revealed a high sensitivity of the studied NDI-polynucleotide systems, thereby providing insight into the aromatic core position within the intercalative binding site.

\section{Conclusion}

The new amino acid conjugates $\mathbf{3 a}, \mathbf{3 b}$, and reference compound 5 bearing the fluorescent NDI tag molecules showed 

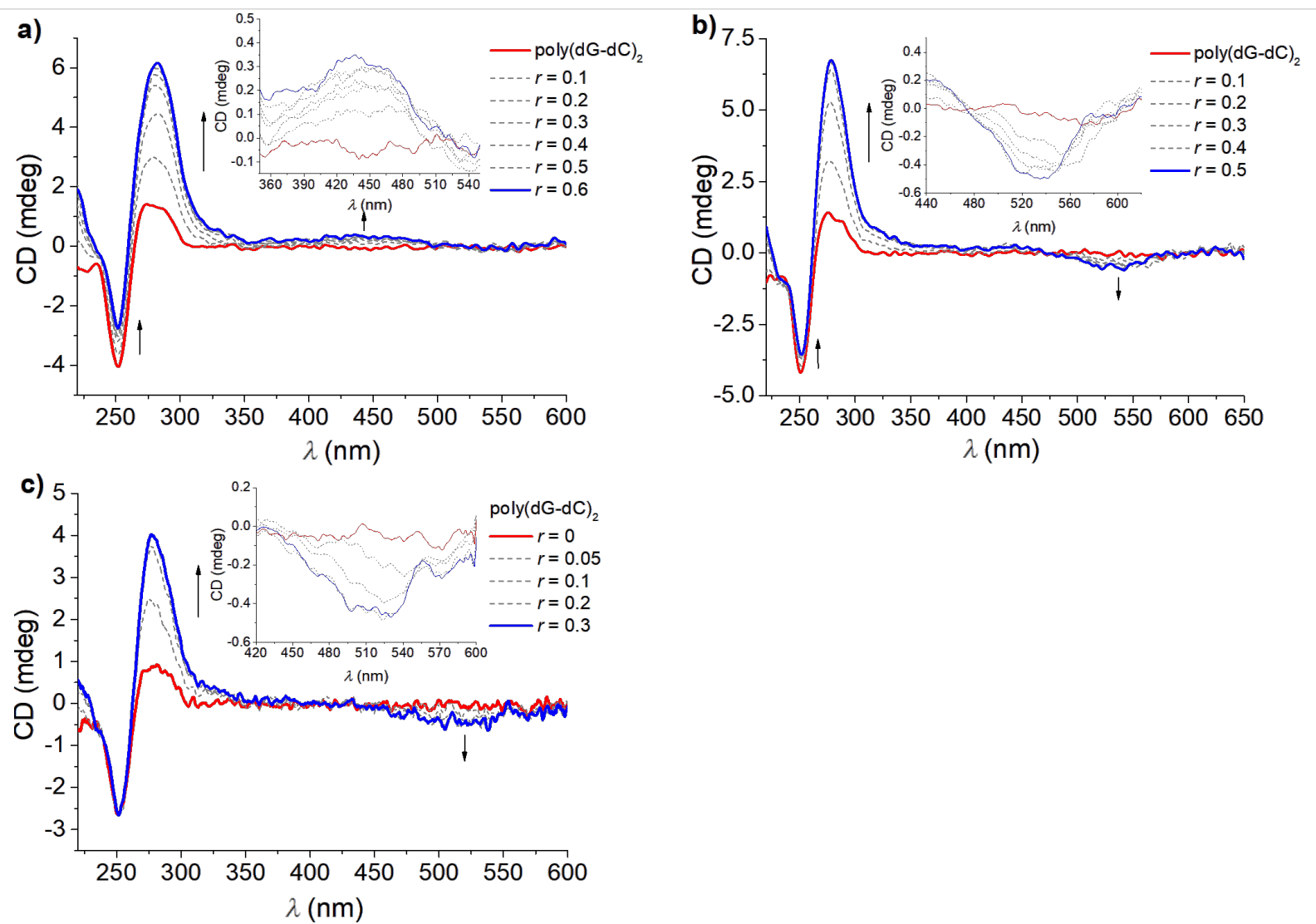

Figure 7: CD titration of poly $(\mathrm{dG}-\mathrm{dC})_{2}\left(c=2.0 \times 10^{-5} \mathrm{M}\right)$ with (a) $\mathbf{3 a}$, (b) $\mathbf{3 b}$, and (c) $\mathbf{5}$ with increasing molar ratios of $r=[\mathrm{NDI}] /[\mathrm{polynucleotide]}$ at $25^{\circ} \mathrm{C}$ (cacodylate buffer, $\mathrm{pH} 5.0, \mathrm{I}=0.05 \mathrm{M}$ ).
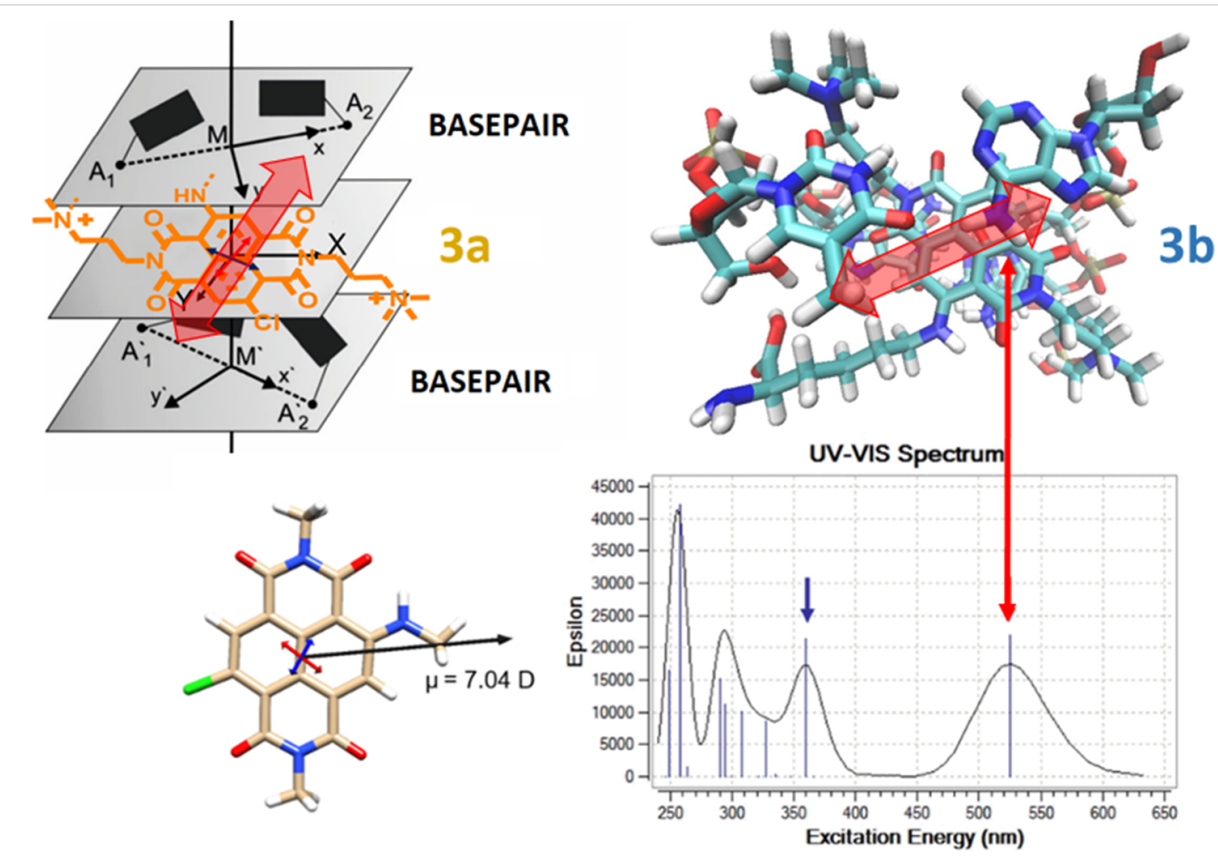

Figure 8: Schematic representation of the alignment of the intercalating $\mathbf{3 a}$ (left) and $\mathbf{3 b}$ (right) between the base pairs of the oligonucleotide. The complex with $\mathbf{3 b}$ was prepared analogously to the NDI analogue [53] by replacing the threading intercalator in PDB258D [54] with 3b, and performing MM2 minimisation in vacuum. Bottom: The orientation of transition dipole moments (red arrow for $450-600 \mathrm{~nm}$ range) according to the calculations made for the spectra shown in Figure 2. 
moderate absorbance in the mid-visible range $\left(\lambda_{\mathrm{abs}}\right.$ $520-540 \mathrm{~nm})$ and significant Stokes shifts of emission (+60 nm) characterised by good quantum yield in aqueous solution. Thus, NDIs 3a and $\mathbf{3 b}$ are novel intensively fluorescent non-natural amino acid probe molecules with both, $\mathrm{N}$ - and $\mathrm{C}$-termini available for incorporation into any peptidoid construct requiring a fluorescent tag.

All studied compounds strongly interact with similar affinity $\left(\log K_{s} 6-7\right)$ with ds-DNA/RNA by intercalation (as confirmed by high thermal stabilisation and CD results), and since intercalation of NDI is only possible by passing one bulky substituent through the polynucleotide double helix, all studied molecules can be regarded as threading intercalators. Complexes with DNA/RNA are additionally stabilised by interactions of positively charged side chains. The spectrophotometric response of these compounds showed pronounced differences and was in some cases highly sensitive on ds-polynucleotide composition and secondary structure. Thus, reference 5 with three permanently charged aliphatic sidechains was non-selective, giving virtually the same fluorimetric and CD response for all DNA/ RNA. In contrast, the introduction of amino acid side chains in 3a and $\mathbf{3 b}$ yielded selective fluorimetric responses between GC and AT(U)-polynucleotides. Moreover, the length and rigidity of the linker to the amino acid unit controlled the positioning of the NDI core inside the intercalative binding site: in GC-DNA, 3a (shorter, more rigid) afforded an ICD band of opposite sign as observed for $\mathbf{3 b}$ or $\mathbf{5}$. This ICD selectivity also depended on the type of polynucleotide, thus we learned that some core-functionalized NDI dyes can directly report the difference between here used GC-DNA, AT-DNA, and AU-RNA.

Since till now various NDI derivatives were applied for binding and sensing different types of DNA/RNA constructs, including G-quartets [55-57], and other, more complex sequences, the herein presented amino acid-NDI conjugates may in future also be investigated for such applications, either directly or incorporated in peptidoid constructs. Indeed, the colourful and fluorescent NDIs $\mathbf{3 a}$ and $\mathbf{3 b}$ are ideal for use in peptide-backbone constructed multichromophores targeting FRET-based sensing $[14,26,58]$. For the application of here presented results in bioanalytical sciences or biologically relevant studies it will be necessary to further modify the presented compounds and precisely collect information about their sensitivity to particular target, read-out accuracy, limits of detection, and selectivity at biorelevant conditions.

\section{Experimental}

All solvents were purchased from commercial sources and used as received. Solvents for spectroscopic studies were of spectroscopic grade. Polynucleotides poly(dA-dT) $)_{2}$, poly(AU), calf thymus (ct)-DNA, and poly $(\mathrm{dG}-\mathrm{dC})_{2}$ were obtained from Sigma-Aldrich. The starting compound $\mathbf{1}$ was prepared according to the literature [31]. Column chromatography was performed on silica gel (MerckSilica 60, particle size 0.04-0.063 mm). Semipreparative HPLC was performed on a Jai system (LC-9105) with a UV-vis detector (UV 3702). The melting points ( $\mathrm{mp}$ ) of compounds were determined with an Olympus BX-41 polarization microscope equipped with a Linkam THMS 600 hot stage and a temperature controller unit. ${ }^{1} \mathrm{H}$ and ${ }^{13} \mathrm{C}$ NMR spectra were recorded in $\mathrm{CD}_{3} \mathrm{OD}, \mathrm{CDCl}_{3}$, $\mathrm{D}_{2} \mathrm{O}$ or DMSO- $d_{6}$ at $298 \mathrm{~K}$ on a Bruker Avance 400 spectrometer. The chemical shifts are reported in ppm and refer to the residual proton signal of the solvent as internal standard. Signal multiplicities are denoted as s (singlet), d (doublet), t (triplet), and $\mathrm{m}$ (multiplet). High-resolution ESI-TOF mass spectrometry was carried out on a MicroTOF focus instrument (BrukerDaltronik $\mathrm{GmbH}$ ). Lyophilisation dryings were carried out using an ALPHA 2-4 LD device from Martin Christ Gefriertrocknungsanlagen $\mathrm{GmbH}$. Only demineralised water (bidistilled water, Milli-Q) was used as the solvent.

Synthesis of $N, N^{\prime}$-bis((3-(trimethylammonium)propyl)amino)-2,6-dichloro-1,4,5,8-naphthalenetetracarboxylic acid diimide diiodide (2): To a solution of $N, N^{\prime}$-bis((3(dimethylamino)propyl)amino)-2,6-dichloro-1,4,5,8-naphthalenetetracarboxylic acid diimide $(1,1.00 \mathrm{~g}, 1.98 \mathrm{mmol})$ in toluene $(90 \mathrm{~mL})$ was added iodomethane $(2.27 \mathrm{~g}, 1.00 \mathrm{~mL}$, $16.0 \mathrm{mmol}$ ). The reaction mixture was stirred at $130{ }^{\circ} \mathrm{C}$ for $2 \mathrm{~h}$. After cooling to room temperature, the resulting light-brown precipitate was collected by filtration, washed with diethyl ether, and dried in vacuum (1.39 g, 89\%). Mp 169-174 ${ }^{\circ} \mathrm{C}$; ${ }^{1} \mathrm{H}$ NMR (DMSO- $\left.d_{6}, 400 \mathrm{MHz}\right) 8.61(\mathrm{~s}, 2 \mathrm{H}), 4.12\left(\mathrm{t},{ }^{3} \mathrm{~J}=\right.$ $6.5 \mathrm{~Hz}, 4 \mathrm{H}), 3.46(\mathrm{~m}, 4 \mathrm{H}), 3.04(\mathrm{~s}, 18 \mathrm{H}), 2.14(\mathrm{~m}, 4 \mathrm{H})$; ${ }^{13} \mathrm{C}$ NMR (DMSO- $\left.d_{6}, 101 \mathrm{MHz}\right) 161.1,160.7,137.6,134.1$, 127.0, 126.3, 122.5, 63.2, 52.2, 37.7, 21.4; HRMS-ESI ${ }^{+}$(methanol, $m / z)$ : $[\mathrm{M}]^{2+}$ calcd for $\mathrm{C}_{26} \mathrm{H}_{32} \mathrm{Cl}_{2} \mathrm{~N}_{4} \mathrm{O}_{4}, 267.0900$; found, 267.0900; UV-vis (MeOH) $\lambda[\mathrm{nm}]\left(\varepsilon\left[\mathrm{M}^{-1} \mathrm{~cm}^{-1}\right]\right) 397$ (10300), 377 (10900), 357 (16000).

Synthesis of (S)- $N, N^{\prime}$-bis((3-(trimethylammonium)propyl)amino)-2-(2-amino-2-carboxyethyl)amino-6-chloro1,4,5,8-naphthalenetetracarboxylic acid diimide dichloride (3a): Diimide (1, $100 \mathrm{mg}, 190 \mu \mathrm{mol})$ and 3-amino-(tert-butoxycarbonyl)-L-alanine $(114 \mathrm{mg}, 560 \mu \mathrm{mol})$ were placed under nitrogen, and dry DMSO (5.0 mL) was added. The reaction mixture was stirred for $1.5 \mathrm{~h}$ at $60{ }^{\circ} \mathrm{C}$. After removal of the solvent under reduced pressure, the residue was purified by preparative HPLC using a C-18 reversed-phase column $\left(\mathrm{CH}_{3} \mathrm{CN} / \mathrm{H}_{2} \mathrm{O} /\right.$ TFA $=25: 75: 0.1)$. $\mathrm{HCl}$ solution $(1 \mathrm{M})$ was added and the solvent was removed by freeze drying yielding a pink solid (50.0 mg, 39\%). Mp 275-279 ${ }^{\circ} \mathrm{C} ;{ }^{1} \mathrm{H}$ NMR $\left(\mathrm{CD}_{3} \mathrm{OD}\right.$, 
$400 \mathrm{MHz}) 8.59(\mathrm{~s}, 1 \mathrm{H}), 8.49(\mathrm{~s}, 1 \mathrm{H}), 4.47(\mathrm{~m}, 1 \mathrm{H}), 4.30(\mathrm{~m}$, $6 \mathrm{H}), 3.57(\mathrm{~m}, 4 \mathrm{H}), 3.16(\mathrm{~s}, 18 \mathrm{H}), 2.28(\mathrm{~m}, 4 \mathrm{H}) ;{ }^{13} \mathrm{C} \mathrm{NMR}$ $\left(\mathrm{CD}_{3} \mathrm{OD}, 101 \mathrm{MHz}\right) 169.8,167.0,163.4,163.3,162.5,152.7$, 135.2, 134.2, 129.1, 128.8, 125.1, 123.1, 122.8, 121.0, 102.7, 65.6, 53.7, 53.7, 53.6, 53.5, 43.6, 39.0, 38.4, 23.2, 23.1; HRMS$\mathrm{ESI}^{+}$(methanol, $\mathrm{m} / \mathrm{z}$ ): $[\mathrm{M}]^{2+}$ calcd for $\mathrm{C}_{29} \mathrm{H}_{39} \mathrm{ClN}_{6} \mathrm{O}_{6}$, 301.1310; found, 301.1317; UV-vis (cacodylate buffer, $\mathrm{pH}$ 5.0) $\lambda[\mathrm{nm}]\left(\varepsilon\left[\mathrm{M}^{-1} \mathrm{~cm}^{-1}\right]\right) 519$ (9100), 369 (9400), 351 (7500), 333 (5000); fluorescence (cacodylate buffer, $\mathrm{pH} 5.0, \lambda_{\mathrm{ex}}=470 \mathrm{~nm}$ ): $\lambda_{\max }[\mathrm{nm}]=581 ; \Phi_{\mathrm{fl}}=0.21$.

Synthesis of (S)- $N, N^{\prime}$-bis((3-(trimethylammonium)propyl)amino)-2- (5-amino-5-carboxypentyl)amino-6-chloro1,4,5,8-naphthalenetetracarboxylic acid diimide dichloride (3b): Diimide (1, $100 \mathrm{mg}, 190 \mu \mathrm{mol})$ and $N_{\alpha^{-}}$(tert-butoxycarbonyl)-L-lysine $(95.0 \mathrm{mg}, 390 \mu \mathrm{mol})$ were placed under nitrogen, and dry DMSO $(5.0 \mathrm{~mL})$ was added. The reaction mixture was stirred for $2 \mathrm{~h}$ at $65^{\circ} \mathrm{C}$. After removal of the solvent under reduced pressure, the residue was purified by preparative HPLC, using a C-18 reversed-phase column $\left(\mathrm{CH}_{3} \mathrm{CN} /\right.$ $\mathrm{H}_{2} \mathrm{O}$ /TFA 25:75:0.1). $\mathrm{HCl}$ solution (1 M) was added and the solvent was removed by freeze drying yielding a pink solid (60.0 mg, 44\%). Mp 272-276 ${ }^{\circ} \mathrm{C} ;{ }^{1} \mathrm{H}$ NMR $\left(\mathrm{CD}_{3} \mathrm{OD}\right.$, $400 \mathrm{MHz}) 8.39(\mathrm{~s}, 1 \mathrm{H}), 8.21(\mathrm{~s}, 1 \mathrm{H}), 4.18(\mathrm{~m}, 4 \mathrm{H}), 3.94(\mathrm{t}$, $\left.{ }^{3} J=6.2 \mathrm{~Hz}, 1 \mathrm{H}\right), 3.61\left(\mathrm{t},{ }^{3} J=6.9 \mathrm{~Hz}, 2 \mathrm{H}\right), 3.46(\mathrm{~m}, 4 \mathrm{H})$, $3.06(\mathrm{~s}, 18 \mathrm{H}), 2.17(\mathrm{~m}, 4 \mathrm{H}), 2.04-1.53(\mathrm{~m}, 6 \mathrm{H}) ;{ }^{13} \mathrm{C}$ NMR $\left(\mathrm{CD}_{3} \mathrm{OD}, 101 \mathrm{MHz}\right) 171.9,167.1,163.6,163.5,162.7,153.1$, $135.2,133.5,129.5,128.8,124.8,123.2,122.6,121.8,100.8$, $65.7,54.0,53.9,53.8,53.8,43.9,39.2,38.6,31.4$, 30.2, 23.8, 23.4, 23.3; HRMS-ESI ${ }^{+}$(methanol, $\mathrm{m} / z$ ): $[\mathrm{M}]^{2+}$ calcd for $\mathrm{C}_{32} \mathrm{H}_{45} \mathrm{ClN}_{6} \mathrm{O}_{6}, 322.1545$; found, 322.1551; UV-vis (cacodylate buffer, $\mathrm{pH} 5.0) \lambda[\mathrm{nm}]\left(\varepsilon\left[\mathrm{M}^{-1} \mathrm{~cm}^{-1}\right]\right) 540$ (9200), 370 (8800), 352 (7700), 335 (5600); fluorescence (cacodylate buffer, pH 5.0, $\left.\lambda_{\mathrm{ex}}=470 \mathrm{~nm}\right): \lambda_{\max }[\mathrm{nm}]=602 ; \Phi_{\mathrm{fl}}=0.10$.

Synthesis of $N, N^{\prime}$-bis((3-(dimethylamino)propyl)amino)-2(2-(dimethylamino)ethyl)amino-6-chloro-1,4,5,8-naphthalenetetracarboxylic acid diimide (4): 2-(Dimethylamino)ethylamine $(52.0 \mathrm{mg}, 0.59 \mathrm{mmol}, 64.5 \mu \mathrm{L})$ was added to a solution of diimide $(\mathbf{1}, 100 \mathrm{mg}, 198 \mu \mathrm{mol})$ in $\mathrm{CH}_{3} \mathrm{CN}(16 \mathrm{~mL})$ and the reaction mixture was stirred for $4 \mathrm{~h}$ at $70{ }^{\circ} \mathrm{C}$ under nitrogen. After removal of the solvent under reduced pressure, the residue was purified by column chromatography $\left(\mathrm{CH}_{2} \mathrm{Cl}_{2} /\right.$ $\mathrm{MeOH} / \mathrm{NEt}_{3}$ 93:7:0.1 $\rightarrow$ 90:10:0.1). Solvent evaporation and drying yielded a red solid $(66.0 \mathrm{mg}, 60 \%)$. Mp: $164-168{ }^{\circ} \mathrm{C}$; ${ }^{1} \mathrm{H} \mathrm{NMR}\left(\mathrm{CDCl}_{3}, 400 \mathrm{MHz}\right) 10.13\left(\mathrm{t},{ }^{3} \mathrm{~J}=5 \mathrm{~Hz}, 1 \mathrm{H}\right), 8.51$ (s, $1 \mathrm{H}), 8.19(\mathrm{~s}, 1 \mathrm{H}), 4.19(\mathrm{~m}, 4 \mathrm{H}), 3.62(\mathrm{~m}, 2 \mathrm{H}), 2.72(\mathrm{~m}, 2 \mathrm{H})$, $2.43(\mathrm{~m}, 4 \mathrm{H}), 2.37(\mathrm{~s}, 6 \mathrm{H}), 2.25(\mathrm{~s}, 12 \mathrm{H}), 1.89(\mathrm{~m}, 4 \mathrm{H})$; ${ }^{13} \mathrm{C} \mathrm{NMR}\left(\mathrm{CDCl}_{3}, 101 \mathrm{MHz}\right) 165.6,162.1,162.0,161.3,151.5$, 134.8, 132.9, 128.1, 127.2, 123.7, 121.8, 121.1, 120.9, 100.1, $58.0,57.3,57.3,45.6,45.5,41.3,39.7,38.8,26.0,25.9$;
HRMS-ESI ${ }^{+}$(methanol, $\left.m / z\right):[\mathrm{M}+\mathrm{H}]^{+}$calcd for $\mathrm{C}_{28} \mathrm{H}_{38} \mathrm{ClN}_{6} \mathrm{O}_{4}, 557.26431$; found, 557.26419; UV-vis $(\mathrm{MeOH}) \lambda[\mathrm{nm}]\left(\varepsilon\left[\mathrm{M}^{-1} \mathrm{~cm}^{-1}\right]\right) 524$ (10800), 364 (9500), 347 (8200), 329 (6400).

Synthesis of $N, N^{\prime}-\operatorname{di}((3-($ trimethylammonium)propyl)amino)-2-(2-(trimethylammonium)ethyl)amino-6chloro-1,4,5,8-naphthalenetetracarboxylic acid diimide trichloride (5): To a solution of diimide (4, $90.0 \mathrm{mg}, 161 \mu \mathrm{mol})$ in acetonitrile $(16 \mathrm{~mL})$ was added iodomethane $(77.8 \mathrm{mg}$, $34.0 \mu \mathrm{L}, 548 \mu \mathrm{mol})$. The reaction mixture was stirred for $3 \mathrm{~d}$ at room temperature. After removal of the solvent under reduced pressure, the residue was purified by preparative HPLC, using a C-18 reversed-phase column $\left(\mathrm{CH}_{3} \mathrm{CN} / \mathrm{H}_{2} \mathrm{O} / \mathrm{TFA}\right.$ 20:80:0.1). $\mathrm{HCl}$ solution $(1 \mathrm{M})$ was added and the solvent was removed by freeze drying yielding a red solid $(50.0 \mathrm{mg}, 44 \%)$. Mp $263{ }^{\circ} \mathrm{C}$; ${ }^{1} \mathrm{H}$ NMR (CD $\left.\mathrm{OD}, 400 \mathrm{MHz}\right) 8.61(\mathrm{~s}, 1 \mathrm{H}), 8.40$ (s, 1H), 4.28 $(\mathrm{m}, 6 \mathrm{H}), 3.84\left(\mathrm{t},{ }^{3} \mathrm{~J}=6.8 \mathrm{~Hz}, 2 \mathrm{H}\right), 3.54(\mathrm{~m}, 4 \mathrm{H}), 3.34(\mathrm{~s}, 9 \mathrm{H})$, $3.14(\mathrm{~s}, 18 \mathrm{H}), 2.27(\mathrm{~m}, 4 \mathrm{H}) ;{ }^{13} \mathrm{C}$ NMR $\left(\mathrm{D}_{2} \mathrm{O}, 101 \mathrm{MHz}\right) 165.3$, 162.46, 162.42, 161.5, 150.9, 134.0, 132.9, 127.2, 126.6, 122.9, 120.9, 120.6, 120.2, 100.6, 63.9, 53.6, 53.0, 53.0, 52.9, 38.0, 37.4, 36.8, 21.4, 21.3; HRMS-ESI ${ }^{+}$(methanol, $\mathrm{m} / \mathrm{z}$ ): $[\mathrm{M}]^{3+}$ calcd for $\mathrm{C}_{31} \mathrm{H}_{46} \mathrm{ClN}_{6} \mathrm{O}_{4}, 200.4423$; found, 200.4423; UV-vis (cacodylate buffer, pH 5.0) $\lambda[\mathrm{nm}]\left(\varepsilon\left[\mathrm{M}^{-1} \mathrm{~cm}^{-1}\right]\right) 518$ (9400), 368 (9800), 350 (7900), 332 (5100); fluorescence (cacodylate buffer, pH 5.0, $\lambda_{\mathrm{ex}}=470 \mathrm{~nm}$ ): $\lambda_{\max }[\mathrm{nm}]=573$; $\Phi_{\mathrm{fl}}=0.32$.

\section{Spectrophotometric studies}

The UV-vis spectra were recorded on a Varian Cary 100 Bio spectrophotometer or on a Jasco V670/770 spectrometer, steady state fluorescence spectra were measured on a PTI QM4/2003 or Varian Eclipse spectrofluorimeter and CD spectra on JASCO J815 spectrophotometer at $25{ }^{\circ} \mathrm{C}$ using appropriate $1 \mathrm{~cm}$ path quartz cuvettes. For study of interactions with DNA and RNA, aqueous solutions of compounds buffered to $\mathrm{pH} 5.0$ (buffer sodium cacodylate, $\mathrm{I}=0.05 \mathrm{~mol} \mathrm{dm}^{-3}$ ) were used. The fluorescence quantum yields were determined by the optically dilute method $(\mathrm{A}<0.05)$ by using $N, N^{\prime}-\operatorname{di}(n$-octyl)-2-chloro- $6-n$ octylamino-1,4,5,8-naphthalenetetracarboxylic acid diimide $\left(\Phi_{\mathrm{fl}}=0.58\right.$ in $\left.\mathrm{CH}_{2} \mathrm{Cl}_{2}\right)$ as standard [25,59]. The reported quantum yields are averaged values obtained at four different excitation wavelengths for each NDI.

Polynucleotides were purchased as noted: poly(dAdT)poly(dAdT), poly(dGdC)-poly(dGdC), poly(A)-poly(U) (Sigma-Aldrich. St. Louis. USA), calf thymus (ct)-DNA (Aldrich). Polynucleotides were dissolved at $\mathrm{pH} 7$ according to manufacturer instructions and diluted 1000-10000 times in $\mathrm{pH}$ 5 buffer of same type (Na-cacodylate buffer, $\mathrm{I}=0.05 \mathrm{M}$ ). The calf thymus ct-DNA was additionally sonicated and filtered 
through a $0.45 \mathrm{~mm}$ filter [60]. The polynucleotide concentration was determined spectroscopically as the concentration of nucleo bases (equimolar to phosphates).

Fluorimetric titrations were performed at $\mathrm{pH} 5.0$ ( $\mathrm{I}=$ $0.05 \mathrm{~mol} \mathrm{dm}^{-3}$, buffer sodium cacodylate) by adding portions of polynucleotide solution into the solution of the studied compound and $\mathrm{CD}$ experiments were done by adding portions of compound stock solution into the solution of polynucleotide. Titration data were processed by the Scatchard equation [4042]. Values for $K_{\mathrm{S}}$ and $n$ given in Table 3 all have satisfactory correlation coefficients $(>0.999)$. Thermal melting curves for DNA, RNA, and their complexes with the studied compounds (Table 2 ) were determined as previously described $[39,61]$ by following the absorption change at $260 \mathrm{~nm}$ as a function of temperature. Absorbance of the ligands was subtracted from every curve and the absorbance scale was normalized. The $T_{\mathrm{m}}$ values are the midpoints of the transition curves determined from the maximum of the first derivative and checked graphically by the tangent method [59]. The $\Delta T_{\mathrm{m}}$ values were calculated by subtracting the $T_{\mathrm{m}}$ value of the free nucleic acid from the $T_{\mathrm{m}}$ value of the complex. Every $\Delta T_{\mathrm{m}}$ value here reported was the average of at least two measurements. The error in $\Delta T_{\mathrm{m}}$ is $\pm 0.5{ }^{\circ} \mathrm{C}$.

In a similar manner as described in [62] ITC were carried out at $293 \mathrm{~K}$ on a MicroCal VP-iTC instrument. In the ITC titration experiments aliquots of the compounds $(28 \times 10 \mu \mathrm{L}, c=$ $0.10-0.15 \mathrm{mM}$ ) were injected from a $280 \mu \mathrm{L}$ rotating syringe (307 rpm) into the calorimeter reaction cell containing $1.4406 \mathrm{~mL}$ of the corresponding polynucleotides $(c=$ $0.05-0.8 \mathrm{mM}$ ). Blank experiments were carried out to determine the heats of dilution of the compounds and the polynucleotides. All solutions used in the ITC experiments were degassed under vacuum prior to use to eliminate air bubbles.

\section{Supporting Information}

\section{Supporting Information File 1 \\ Copies of ${ }^{1} \mathrm{H},{ }^{13} \mathrm{C}$ NMR spectra, HRMS spectra, and titration data on the binding of water-soluble NDI compounds $\mathbf{3 a}, \mathbf{b}$ and $\mathbf{5}$ with DNA/RNA. [https://www.beilstein-journals.org/bjoc/content/ supplementary/1860-5397-16-170-S1.pdf]}

\section{Acknowledgements}

The here reported results are part of the doctoral thesis of Annike Weißenstein, Julius-Maximilians-Universität Würzburg, 2018.

\section{Funding}

Financial support of this work by Croatian Science Foundation project IP-2018-01-5475 is gratefully acknowledged.

\section{ORCID ${ }^{\circledR}$ iDs}

Ivo Piantanida - https://orcid.org/0000-0002-9933-446X

Frank Würthner - https://orcid.org/0000-0001-7245-0471

\section{References}

1. Matić, J.; Tumir, L.-M.; Radić Stojković, M.; Piantanida, I. Curr. Protein Pept. Sci. 2016, 17, 127-134. doi:10.2174/138920371702160209124439

2. Inmels, H.; Otto, D. Intercalation of organic dye molecules into double-stranded DNA - general principles and recent developments. In Supermolecular Dye Chemistry; Würthner, F., Ed.; Topics in Current Chemistry, Vol. 258; Springer: Berlin, Germany, 2005; pp 161-204. doi:10.1007/b135804

3. Dervan, P. B.; Edelson, B. S. Curr. Opin. Struct. Biol. 2003, 13, 284-299. doi:10.1016/s0959-440x(03)00081-2

4. Müller, S.; Paulus, J.; Mattay, J.; Ihmels, H.; Dodero, V. I.; Sewald, N. Beilstein J. Org. Chem. 2020, 16, 60-70. doi:10.3762/bjoc.16.8

5. Bhaduri, S.; Ranjan, N.; Arya, D. P. Beilstein J. Org. Chem. 2018, 14, 1051-1086. doi:10.3762/bjoc.14.93

6. Kaur, G.; Lewis, J. S.; van Oijen, A. M. Molecules 2019, 24, No. 491. doi:10.3390/molecules24030491

7. Specht, E. A.; Braselmann, E.; Palmer, A. E. Annu. Rev. Physiol. 2017, 79, 93-117. doi:10.1146/annurev-physiol-022516-034055

8. Demeunynck, M.; Bailly, C.; Wilson, W. D., Eds. Small Molecule DNA and RNA Binders: From Synthesis to Nucleic Acid Complexes; Wiley-VCH: Weinheim, Germany, 2004. doi:10.1002/3527601783

9. Lavis, L. D. Biochemistry 2017, 56, 5165-5170. doi:10.1021/acs.biochem.7b00529

10. Teo, Y. N.; Kool, E. T. Chem. Rev. 2012, 112, 4221-4245. doi:10.1021/cr100351g

11. Šmidlehner, T.; Rožman, A.; Piantanida, I. Curr. Protein Pept. Sci. 2019, 20, 1040-1045. doi:10.2174/1389203720666190513084102 12. Matić, J.; Šupljika, F.; Tandarić, T.; Dukši, M.; Piotrowski, P.; Vianello, R.; Brozović, A.; Piantanida, I.; Schmuck, C.; Radić Stojković, M. Int. J. Biol. Macromol. 2019, 134, 422-434. doi:10.1016/j.ijbiomac.2019.05.063

13. Šmidlehner, T.; Kurutos, A.; Slade, J.; Belužić, R.; Ang, D. L.; Rodger, A.; Piantanida, I. Eur. J. Org. Chem. 2018, 1682-1692. doi:10.1002/ejoc.201701765

14. Šmidlehner, T.; Badovinac, M.; Piantanida, I. New J. Chem. 2018, 42, 6655-6663. doi:10.1039/c8nj00055g

15. Maity, D.; Matković, M.; Li, S.; Ehlers, M.; Wu, J.; Piantanida, I.; Schmuck, C. Chem. - Eur. J. 2017, 23, 17356-17362. doi:10.1002/chem.201703813

16. Wu, J.; Zou, Y.; Li, C.; Sicking, W.; Piantanida, I.; Yi, T.; Schmuck, C. J. Am. Chem. Soc. 2012, 134, 1958-1961. doi:10.1021/ja2103845

17. Suraru, S.-L.; Würthner, F. Angew. Chem., Int. Ed. 2014, 53, 7428-7448. doi:10.1002/anie.201309746

18. Al Kobaisi, M.; Bhosale, S. V.; Latham, K.; Raynor, A. M.; Bhosale, S. V. Chem. Rev. 2016, 116, 11685-11796. doi:10.1021/acs.chemrev.6b00160

19. Maniam, S.; Higginbotham, H. F.; Bell, T. D. M.; Langford, S. J. Chem. - Eur. J. 2019, 25, 7044-7057. doi:10.1002/chem.201806008 
20. Cox, R. P.; Sandanayake, S.; Scarborough, D. L. A.; Izgorodina, E. I.; Langford, S. J.; Bell, T. D. M. New J. Chem. 2019, 43, 2011-2018. doi:10.1039/c8nj05666h

21. Czerwinska, I.; Sato, S.; Juskowiak, B.; Takenaka, S. Bioorg. Med. Chem. 2014, 22, 2593-2601. doi:10.1016/j.bmc.2014.03.034

22. Rhoden Smith, A.; Iverson, B. L. J. Am. Chem. Soc. 2013, 135, 12783-12789. doi:10.1021/ja4057344

23. Würthner, F.; Ahmed, S.; Thalacker, C.; Debaerdemaeker, T. Chem. - Eur. J. 2002, 8, 4742-4750. doi:10.1002/1521-3765(20021018)8:20<4742::aid-chem4742>3.0.co;2I

24. Kim, M. B.; Dixon, D. W. J. Phys. Org. Chem. 2008, 21, 731-737. doi:10.1002/poc.1334

25. Thalacker, C.; Röger, C.; Würthner, F. J. Org. Chem. 2006, 71, 8098-8105. doi:10.1021/j00612269

26. Saftić, D.; Radić Stojković, M.; Žinić, B.; Glavaš-Obrovac, L.; Jukić, M.; Piantanida, I.; Tumir, L.-M. New J. Chem. 2017, 41, 13240-13252. doi:10.1039/c7nj02699d

27. Radić Stojković, M.; Piotrowski, P.; Schmuck, C.; Piantanida, I. Org. Biomol. Chem. 2015, 13, 1629-1633. doi:10.1039/c4ob02169j

28. Schäfer, K.; Ihmels, H.; Porcù, E.; Viola, G. Chem. - Eur. J. 2017, 23 , 370-379. doi:10.1002/chem.201603807

29. Wong, P.; Lee, C.; Tannock, I. F. Clin. Cancer Res. 2005, 11, 3553-3557. doi:10.1158/1078-0432.ccr-04-2472

30. Manallack, D. T.; Prankerd, R. J.; Yuriev, E.; Oprea, T. I.; Chalmers, D. K. Chem. Soc. Rev. 2013, 42, 485-496. doi:10.1039/c2cs35348b

31. Weißenstein, A.; Grande, V.; Saha-Möller, C. R.; Würthner, F. Org. Chem. Front. 2018, 5, 2641-2651. doi:10.1039/c8qo00611c

32. Gaussian 09; Gaussian, Inc.: Wallingford, CT, 2009.

33. Sakai, N.; Mareda, J.; Vauthey, E.; Matile, S. Chem. Commun. 2010, 46, 4225-4237. doi:10.1039/c0cc00078g

34. Pugliesi, I.; Megerle, U.; Suraru, S.-L.; Würthner, F.; Riedle, E.; Lochbrunner, S. Chem. Phys. Lett. 2011, 504, 24-28. doi:10.1016/j.cplett.2011.01.038

35. Casagrande, V.; Alvino, A.; Bianco, A.; Ortaggi, G.; Franceschin, M. J. Mass Spectrom. 2009, 44, 530-540. doi:10.1002/jms.1529

36. Cantor, C. R.; Schimmel, P. R. Biophysical Chemistry; WH Freeman and Co.: San Francisco, CA, USA, 1980; Vol. 3.

37. Egli, M.; Saenger, W. Principles of Nucleic Acid Structure; Springer: New York, NY, USA, 1983

38. Hewitt, W. M.; Calabrese, D. R.; Schneekloth, J. S., Jr. Bioorg. Med. Chem. 2019, 27, 2253-2260. doi:10.1016/j.bmc.2019.04.010

39. Mergny, J.-L.; Lacroix, L. Oligonucleotides 2003, 13, 515-537. doi:10.1089/154545703322860825

40. Scatchard, G. Ann. N. Y. Acad. Sci. 1949, 51, 660-672. doi:10.1111/j.1749-6632.1949.tb27297.x

41. McGhee, J. D.; von Hippel, P. H. J. Mol. Biol. 1974, 86, 469-489. doi:10.1016/0022-2836(74)90031-x

42. McGhee, J. D.; von Hippel, P. H. J. Mol. Biol. 1976, 103, 679. doi:10.1016/0022-2836(76)90228-x

43. Piantanida, I.; Palm, B. S.; Žinić, M.; Schneider, H.-J. J. Chem. Soc., Perkin Trans. 2 2001, 1808-1816. doi:10.1039/b103214n

44. Chaires, J. B. Arch. Biochem. Biophys. 2006, 453, 26-31. doi:10.1016/j.abb.2006.03.027
45. Breslauer, K. J.; Remeta, D. P.; Chou, W. Y.; Ferrante, R.; Curry, J.; Zaunczkowski, D.; Snyder, J. G.; Marky, L. A. Proc. Natl. Acad. Sci. U. S. A. 1987, 84, 8922-8926. doi:10.1073/pnas.84.24.8922

46. MicroCal, ITC Data Analysis in Origin - Tutorial Guide; 1998.

47. Freyer, M. W.; Lewis, E. A. Isothermal titration calorimetry: experimental design, data analysis, and probing macromolecule/ligand binding and kinetic interactions. Methods in Cell Biology; Academic Press: New York, NY, USA, 2008; Vol. 84, pp 79-113. doi:10.1016/s0091-679x(07)84004-0

48. Ladbury, J. E.; Chowdhry, B. Z. Biocalorimetry: Applications of Calorimetry in the Biological Sciences; John Wiley \& Sons, Inc.: Chichester, UK, 1998.

49. Eriksson, M.; Nordén, B. Linear and circular dichroism of drug-nucleic acid complexes. In Methods in Enzymology; Chaires, J. B.; Waring, M. J., Eds.; Academic Press: San Diego, CA, USA, 2001; Vol. 340, pp 68-98. doi:10.1016/s0076-6879(01)40418-6

50. Šmidlehner, T.; Piantanida, I.; Pescitelli, G. Beilstein J. Org. Chem. 2018, 14, 84-105. doi:10.3762/bjoc.14.5

51. Murr, M. M.; Harting, M. T.; Guelev, V.; Ren, J.; Chaires, J. B.; Iverson, B. L. Bioorg. Med. Chem. 2001, 9, 1141-1148. doi:10.1016/s0968-0896(00)00335-7

52. Strekowski, L.; Wilson, B. Mutat. Res., Fundam. Mol. Mech. Mutagen. 2007, 623, 3-13. doi:10.1016/j.mrfmmm.2007.03.008

53. Lee, J.; Guelev, V.; Sorey, S.; Hoffman, D. W.; Iverson, B. L. J. Am. Chem. Soc. 2004, 126, 14036-14042. doi:10.1021/ja046335o

54. Smith, C. K.; Brannigan, J. A.; Moore, M. H. J. Mol. Biol. 1996, 263 , 237-258. doi:10.1006/jmbi.1996.0572

55. Zou, T.; Sato, S.; Yasukawa, R.; Takeuchi, R.; Ozaki, S.; Fujii, S.; Takenaka, S. Molecules 2020, 25, No. 668. doi: $10.3390 /$ molecules 25030668

56. Sato, S.; Kajima, A.; Hamanaka, H.; Takenaka, S. J. Organomet. Chem. 2019, 897, 107-113. doi:10.1016/j.jorganchem.2019.06.028

57. Kaneyoshi, S.; Zou, T.; Ozaki, S.; Takeuchi, R.; Udou, A.; Nakahara, T.; Fujimoto, K.; Fujii, S.; Sato, S.; Takenaka, S. Chem. - Eur. J. 2020, 26, 139-142. doi:10.1002/chem.201903883

58. Ban, Ž.; Matić, J.; Žinić, B.; Foller Fuchtbauer, A.; Wilhelmsson, L. M.; Piantanida, I. Molecules 2020, 25, No. 2188. doi:10.3390/molecules25092188

59. Lakowitz, J. R. Principles of Fluorescence Spectroscopy, 2nd ed.; Kluwer Acacemic Publishers: New York, NY, USA, 1999; p 52.

60. Chaires, J. B.; Dattagupta, N.; Crothers, D. M. Biochemistry 1982, 21 , 3933-3940. doi:10.1021/bi00260a005

61. Tumir, L.-M.; Piantanida, I.; Juranović Cindrić, I.; Hrenar, T.; Meić, Z.; Žinić, M. J. Phys. Org. Chem. 2003, 16, 891-899. doi:10.1002/poc.680

62. Klemm, K.; Radić Stojković, M.; Horvat, G.; Tomišić, V.; Piantanida, I.; Schmuck, C. Chem. - Eur. J. 2012, 18, 1352-1363. doi:10.1002/chem.201101544 


\section{License and Terms}

This is an Open Access article under the terms of the Creative Commons Attribution License (https://creativecommons.org/licenses/by/4.0). Please note that the reuse, redistribution and reproduction in particular requires that the authors and source are credited.

The license is subject to the Beilstein Journal of Organic Chemistry terms and conditions:

(https://www.beilstein-journals.org/bjoc)

The definitive version of this article is the electronic one which can be found at:

https://doi.org/10.3762/bjoc.16.170 